\title{
Guru Profesional Menurut Imam Al-Ghazali dan Buya Hamka
}

\author{
M. YUSUF AHMAD* \\ BALO SIREGAR** \\ *Fakultas Agama Islam (FAI) Universitas Islam Riau (UIR) Pekanbaru \\ Jl. Kaharuddin Nasution, No. 113, Perhentian Marpoyan Pekanbaru 28284 \\ **Fakultas Agama Islam (FAI) Universitas Islam Riau (UIR) Pekanbaru \\ Jl. Kaharuddin Nasution, No. 113, Perhentian Marpoyan Pekanbaru 28284
}

\begin{abstract}
Abstrak: Salah satu solusi dari permasalahan yang ada pada pendidikan di Indonesia adalah menjadikan para guru sebagai seseorang yang profesional yang memiliki kompetensi di bidangnya. Penelitian ini mengangkat topik tentang guru profesional menurut Imam al-Ghazali dan Buya Hamka (Studi Komparatif). Kedua tokoh ini adalah tokoh yang hidup pada masa dan negeri yang berbeda, bahkan menganut aliran pemahaman yang berbeda pula. Tujuan dalam penelitian ini adalah untuk mengetahui bagaimana guru profesional menurut Imam al-Ghazali dan Buya Hamka, dan bagaimanakah perbandingan guru profesional menurut Imam al-Ghazali dan Buya Hamka. Penelitian yang dilakukan ini adalah termasuk dalam jenis penelitian deskriptif kualitatif dengan library research. Metode yang digunakan adalah deskriptif analitis kritis, sumber data primernya adalah karya-karya Imam al-Ghazali dan Buya Hamka yang berhubungan dengan guru profesional dan data sekundernya adalah karya-karya yang serupa yang mempunyai tema sama. Analisis pada penelitian ini menggunakan cara content analysis atau analisa isi yaitu pengolahan data dengan cara pemilahan tersendiri berkaitan dengan pembahasan dari beberapa gagasan atau pemikiran para tokoh pendidikan yang kemudian dideskripsikan, dibahas dan dikritik. Hasil penelitian menunjukkan bahwa guru profesional menurut Imam al-Ghazali dan Buya Hamka memiliki persamaan dan ada perbedaan:Diantara persamaan pendapat mereka adalah bahwa guru menjadi teladan bagi peserta didik, memiliki prinsip dan kasih sayang dll. Sedangkan perbedaan pendapat mereka yaitu menurut Buya Hamka guru harus mampu bersosialisasi dengan masyarakat sedangkan Imam al-Ghazali tidak memiliki pemikiran itu jadi penulis anggap berbeda dll.
\end{abstract}

Kata kunci: Guru Profesional, Imam al-Ghazali, Buya Hamka

\section{PENDAHULUAN}

Dunia pendidikan tak terlepas dari campur tangan guru, yang merupakan komponen penting dalam dunia pendidikan. Peran aktif guru, guna mencerdaskan kehidupan bangsa sangat besar. Guru menjadi panutan, suri tauladan bagi setiap muridnya. Tak dapat dipungkiri lagi bahwa guru adalah simbol terbentuknya akhlak siswa.

Dalam kasus jabatan guru, National Education Association (NEA) 
(1948) merumuskan bahwa jabatan profesi merupakan jabatan yang melibatkan kegiatan intlektual, menekuni suatu batang ilmu tertentu, didahului dengan persiapan profesional yang lama, memerlukan pelatihan jabatan yang kontinyu, menjanjikan karir bagi anggota secara permanen, mengikuti standar baku mutu tersendiri, lebih mementingkan layanan kepada masyarakat dibanding dengan mencari keuntungan pribadi, dan memiliki organisasi profesional yang kuat dan dapat melakukan kontrol terhadap anggota yang melakukan penyimpangan (H. Syaiful Sagala: 2011: 8).

Guru adalah salah satu komponen manusiawi dalam proses belajar mengajar, yang ikut berperan dalam usaha pembentukan sumber daya manusia yang profesional di bidang pembangunan. Oleh karena itu, guru yang merupakan salah satu unsur di bidang kependidikan harus berperan serta secara aktif dan menempatkan kedudukannya sebagai tenaga profesional, sesuai dengan tuntutan masyarakat yang semakin berkembang. Dalam arti khusus dapat dikatakan bahwa setiap diri guru itu terletak tanggung jawab untuk membawa peserta didik pada suatu kedewasaan atau taraf kematangan tertentu. Dalam rangka ini guru tidak semata-mata sebagai pengajar yang melakukan transfer of knowledge, tetapi juga sebagai pendidik yang melakukan transfer of values dan sekaligus sebagai pembimbing yang memberikan pengarahan dan menuntun siswa dalam belajar. Berkaitan dengan ini, sebenarnya guru memiliki peranan yang unik dan sangat kompleks di dalam proses belajar-mengajar, yakni dalam usahanya untuk mengantarkan peserta didik ke taraf yang dicita-citakan (M. Yusuf Ahmad: 2011, 44-45).
Moh. Ali, di dalam buku menjadi guru profesional karangan Moh. Uzer Usman, mengatakan tugas dan tanggung jawab guru yang begitu kompleksnya, maka profesi ini memerlukan persyaratan khusus antara lain dikemukakan berikut ini: (1) Menuntut adanya keterampilan yang berdasarkan konsep dan teori ilmu pengetahuan yang mendalam; (2) Menekankan pada suatu keahlian dalam bidang tertentu sesuai dengan bidang profesinya; (3) Menurut adanya tingkat pendidikan keguruan yang memadai; (4) Adanya kepekaan terhadap dampak kemasyarakatan dari pekerjaan yang dilaksanakannya; dan (5) Memungkinkan perkembangan sejalan dengan dinamika kehidupan (Usman, 2005:11).

Selain syarat tersebut, Moh. Uzer Usman mengatakan terdapat beberapa persyaratan yang harus dipenuhi oleh setiap orang yang tergolong kedalam suatu profesi antara lain: (1) Memiliki kode etik, sebagai acuan dalam melaksanakan tugas dan fungsinya; (2) Memiliki klien/objek layanan yang tetap, seperti dokter dengan pasiennya, guru dengan muridnya; dan (3) Diakui oleh masyarakat karena memang diperlukan jasanya di masyarakat (Usman, 2005: 13).

Atas dasar di atas tersebut, jabatan profesional harus ditempuh melalui jenjang pendidikan yang khusus mempersiapkan jabatan itu. Demikian pun dengan profesi guru, harus ditempuh melalui jenjang pendidikan pre service education seperti Pendidikan Guru Sekolah Dasar (PGSD) IKIP, fakultas keguruan (Usman, 2005: 1516).

Tugas-tugas guru yang bersifat profesional harus ditunjang oleh sistem penghargaan. Dengan begitu para guru jadi bersedia memfokuskan diri pada peningkatan kualitas layanan yang diberikan. Kalau itu tercapai, berarti 
sejalan dengan kreteria pekerjaan profesional yang menyebutkan bahwa guru berhak mendapatkan imbalan layak. Bukan hanya dalam bentuk materi, tapi juga bentuk penghargaan tadi, seperti rasa hormat maupun rasa segan masyarakat terhadap guru. Bila sampai penghargaan maupun pemberian imbalan terabaikan, maka citra guru profesional tidak akan muncul.

Guru profesional, setelah mangacu pada ciri profesional seperti diuraikan sebelumnya dan telah memperoleh sertifikat pendidikan, bukanlah seperti seorang teknisi atau tukang kayu yang menunggu perintah dari atasan. Guru profesional harus mampu mengambil keputusan serta membuat rencana yang disesuaikan dengan siswa, situasi, wawasan sendiri, nilai sekaligus komitmennya. Harus mampu pula mengambil keputusan situasional dan transaksional.

Keputusan situasional perlu diambil sewaktu melaksanakan pembelajaran di kelas. Sementara keputusan transaksional diperlukan ketika mengelola proses pembelajaran secara integral yang berdampak lebih luas dan berjangka panjang (Sembiring, 2009: 170-171).

Guru profesional adalah guru yang memiliki kemampuan dan keahlian khusus dalam bidang keguruan sehingga ia mampu melakukan tugas dan fungsinya sebagai guru dengan kemampuan maksimal. Selanjutnya Agus F. Tamyong mengatakan dalam Moh. Uzer Usman, guru profesional adalah orang yang terdidik dan terlatih dengan baik, serta memiliki pengalaman yang kaya di bidangnya (Usman, 2005: 15).

Selain mampu memutuskan sumber dan media belajar apa yang akan digunakan para guru profesional (atau guru sejati) juga harus menguasai strategi pembelajaran serta evaluasi yang bakal diterapkan. Seorang guru harus mampu membaca situasi secara berkesinambungan. Terutama yang berkaitan dengan respons siswa. Disini guru harus mampu melakukan berbagai penyesuaian bila diperlukan. Guru harus mampu melakukan analisis reklektif saat pembelajaran sedang berlangsung terhadap apa yang terjadi di dalam kelas termasuk juga apa yang telah dicapai para siswa. Dan hasil analisis-reklektif ini dapat digunakan untuk memperbaiki perencanaan dan pelaksanaan pembelajaran berikutnya (Sembiring, 2009: 171).

Dalam undang-undang RI No. 14 tahun 2005 pasal 7 tentang guru dan dosen ada beberapa prinsip profesionalitas guru, yaitu: (1) Memiliki bakat, minat, panggilan jiwa, dan idealisme; (2) Memiliki komitmen untuk meningkatkan mutu pendidikan, keimanan, ketakwaan, dan akhlak mulia; (3) Memiliki kualifikasi akademik dan latar belakang pendidikan sesuai dengan bidang tugas; (4) Memiliki kompetensi yang diperlukan sesuai dengan bidang tugas; (5) Memiliki tanggung jawab atas pelaksanaan tugas keprofesionalan; (6) Memperoleh penghasilan yang ditentukan sesuai dengan prestasi kerja; (7) Memiliki kesempatan untuk mengembangkan keprofesionalan secara berkelanjutan dengan belajar sepanjang hayat; (8) Memiliki jaminan hukum dan melaksanakan tugas keprofesionalan; dan (9) Memiliki organisasi profesi yang mempunyai kewenangan mengatur halhal yang berkaitan dengan tugas keprofesionalan (Guza, 2006: 6).

Yang dirasakan sekarang adalah adanya ketertinggalan di dalam mutu pendidikan. Baik pendidikan formal maupun informal. Pendidikan memang telah menjadi penopang dalam meningkatkan sumber daya manusia Indonesia untuk pembangunan bangsa. 
Setelah diamati, tampak jelas bahwa masalah yang serius dalam mutu pendidikan di Indonesia adalah rendahnya jumlah guru profesional dalam di berbagai jenjang pendidikan, baik pendidikan formal maupun informal. Dan hal itulah yang menyebabkan rendahnya mutu pendidikan yang kemudian menghambat penyediaan sumber daya menusia yang mempunyai keahlian dan keterampilan untuk memenuhi pembangunan bangsa di berbagai bidang.

Di dalam undang-undang guru dan dosen nomor 14 tahun 2005 bab I pasal 1, guru adalah pendidik profesional dengan tugas utama mendidik, mengajar, membimbing, mengarahkan, melatih, menilai, dan mengevaluasi peserta didik pada pendidikan usia dini jalur pendidikan formal, pendidikan dasar, dan pendidikan menengah (Guza, 2009: 2).

Persamaan yang paling esensial, bahwa guru dan dosen adalah pendidik yang merupakan tenaga profesional. "profesional adalah pekerjaan atau kegiatan yang dilakukan seseorang dan menjadi sumber penghasilan kehidupannya yang memerlukan keahlian, kemahiran, dan kecakapan yang memenuhi standar mutu atau norma tertentu, serta memerlukan pendidikan profesi" (Anwar Arifin, 2007: 44).

Kata profesional berasal dari kata sifat yang berarti pencaharian dan sebagai kata benda yang berarti orang yang mempunyai keahlian seperti guru, dokter, hakim dan sebagainya. Dengan kata lain pekerjaan yang bersifat profesional adalah pekerjaan yang hanya dapat dilakukan oleh mereka yang khusus dipersiapkan untuk itu dan bukan pekerjaan yang dilakukan oleh mereka yang karena tidak dapat memperoleh pekerjaan lain (M. Yusuf Ahmad, 2011: 75).

Dengan bertitik tolak pada pengertian di atas, maka pengertian guru profesional adalah guru yang memiliki kemampuan dan keahlian khusus dalam bidang keguruan sehingga ia mampu melakukan tugas dan fungsinya sebagai guru dengan kemampuan maksimal (Moh. Uzer Usman, 2009: 15).

Menurut Kunandar guru profesional adalah guru yang memiliki potensi yang dipersyaratkan untuk melakukan tugas pendidikan dan pengajaran. Kompetensi disini meliputi pengetahuan, sikap dan keterampilan profesional, baik yang bersifat pribadi, sosial, maupun akademis (Kunandar, 2011: 46).

Dari pengertian di atas penulis dapat simpulkan bahwa guru profesional adalah guru yang memiliki skill mengajar yang sangat baik, memiliki wawasan yang sangat luas, mempunyai akhlak yang mulia. Dapat bermitra dengan orang tua dan masyarakat secara baik dan menguasai bidang yang diajarkan dan mengajar dengan humanis.

Di dalam Undang-Undang Nomor 14 tahun 2005 pada pasal 10 dijelaskan guru professional adalah guru yang memiliki 4 kompetensi : Kopetensi kepribadian, kompetensi pedagogik, kompetesi profesional dan kompetensi sosial.

Dalam penjelasan Undang-Undang Nomor 14 tahun 2005 dikemukakan yang dimaksud dengan kompetensi pedagogik adalah kemampuan mengelola pembelajaran peserta didik. Yang dimaksud dengan kompetensi kepribadian adalah kemampuan kepribadian yang mantap, berakhlak mulia, arif, dan berwibawa serta menjadi teladan peserta didik. Yang dimaksud dengan kompetensi 
profesional adalah kemampuan penguasaan materi pelajaran secara luas dan mendalam. Sedangkan yang dimaksud kompetensi sosial adalah kemampuan guru untuk berkomunikasi dan berinteraksi secara efektif dan efisien dengan peserta didik, sesama guru, orang tua/wali peserta didik, dan masyarakat sekitar.

Suatu pekerjaan profesional memerlukan persyaratan khusus, yaitu: (a) Menuntut adanya keterampilan berdasarkan konsep dan teori ilmu pengetahuan yang mendalam; (b) Menekankan pada suatu keahlian dalam bidang tertentu sesuai dengan bidang profesinya; (c) Menuntut adanya tingkat pendidikan yang memadai; (d) Adanya kepekaan terhadap dampak kemasyarakatan dari pekerjaan yang dilaksanakannya; dan (e) Memungkinkan perkembangan sejalan dengan dinamika kehidupan (Moh. Ali, dalam Kunandar, 2011).

Selain persyaratan di atas, Usman menambahkan, yaitu: (a) Memiliki kode etik, sebagai acuan dalam melaksanakan tugas dan fungsinya; (b) Memiliki klien/objek layanan yang tetap, seperti dokter dengan pasiennya, guru dengan muridnya; dan (c) Diakui oleh masyarakat karena memang diperlukan jasanya di masyarakat (Usman, dalam Kunandar, 2011: 47).

Dengan kata lain guru yang profesional adalah seorang guru yang mempunyai kemampuan yang personal yang mencakup: (1) Penampilan dan sikap yang positif keseluruhan tugasnya sebagai guru, dan terhadap keseluruhan situasi pendidikan; (2) Pemahaman dan penghayatan serta penampilan terhadap nilai-nilai yang sepantasnya dilakukan dan dimiliki guru; dan (3) Penampilan diri sebagai panutan dan teladan bagi para siswa (Nana Syaodih: 1979, 191).

Jadi, salah satu solusi dari kasus pendidikan di Indonesia adalah dicarikan guru yang profesional, karna guru yang profesional itu sudah memiliki kompetensi di bidangnya.

Seorang guru yang baik memiliki keterampilan manajemen kelas yang baik dan dapat memastikan perilaku siswa yang baik, saat siswa belajar dan bekerja sama secara efektif, membiasakan menanamkan rasa hormat kepada seluruh komponen didalam kelas.

Sesuai dengan permasalahan di atas, tujuan yang ingin dicapai dalam penelitian ini adalah untuk mengetahui bagaimana guru profesional menurut Imam al-Ghazali dan Buya Hamka, dan bagaimanakah perbandingan guru profesional menurut Imam al-Ghazali dan Buya Hamka.

\section{METODE}

Penelitian tentang guru profesional menurut Imam al-Ghazali dan Buya Hamka, merupakan penelitian yang didasarkan pada penelitian kepustakaan (library research). Yaitu dengan menelaah buku-buku karya Imam al-Ghazali dan buku-buku karya Buya Hamka sebagai sumber data primer, dan buku-buku yang ditulis oleh orang lain mengenai guru profesional sebagai sumber data skunder.

Karena penulisan ini adalah penilitian kepustakaan (Library Research) maka data-data yang diambil barasal dari berbagai sumber tulisan, baik dari majalah, tulisan ilmiyah, internet dan lain-lain yang bersangkutan dengan materi yang penulis bahas.

Adapun sumber penelitian ini diantaranya adalah: (1) Sumber data primer. Data primer adalah data yang penulis peroleh dari karya Imam alGhazali yaitu Ihya 'Ulumiddin. dan karya-karya tulis Buya Hamka yang berkaitan dengan guru profesional 
seperti Lembaga Hidup, Lembaga Budi; dan (2) Sumber Data Sekunder. Data sekunder diperoleh dari buku-buku yang membahas tentang guru profesional yang ditulis oleh tokohtokoh yang lain dan ensiklopedi.

Pengumpulan data digali dari sumber kepustakaan. Setelah data yang diperlukan terkumpul, selanjutnya diadakan klasifikasi dan dianalisa dengan menggunakan metode analisa Content Analysis. Data yang dikehendaki dalam penelitian ini adalah data kualitatif, oleh karena itu dalam menganalisis data tersebut menggunakan metode content analysis atau analisis data. Karena content analysis merupakan bagian metode penelitan dokumen, maka untuk menggambarkan dengan jelas metode Content Analysis yang positifistic kualitatatif (Moleong, 2000:163)

Setelah data terkumpul, kemudian dianalisa dengan menggunakan metode deskriptif analisis. Metode analisis yaitu jalan yang ditempuh untuk mendapatkan ilmu pengetahuan ilmiah dengan mengadakan pemerincian terhadap objek yang diteliti atau cara penanganan terhadap suatu objek ilmiah tertentu dengan jalan memilahmilah antara pengertian yang satu dengan pengertian yang lain guna sekedar memperoleh kejelasan mengenai suatu hal. Setelah itu, perlu dilakukan telaah lebih lanjut guna mengkaji secara sistematis dan objektif.

Setelah konsep guru profesional menurut Imam al-Ghazali dan Buya Hamka diketahui melalui kontent analysis, maka selanjutnya adalah membandingkan antara dua konsep tersebut untuk menghasilkan konsep guru profesional menurut Imam alGhazali dan Buya Hamka yang sesuai dengan konsep sekarang.
HASIL

Imam al-Ghazali Riwayat Hidup

Imam al-Ghazali lahir pada tahun 450 H/1059 M di Thusia sebuah kota di Khurasan, Persia. Nama lengkapnya adalah Abu Hamid Muhammad bin Muhammad al-Ghazali. Beliau terkenal sebagai seorang ahli fiqih (Hukum), ahli kalam (Teologi), pemikir yang original, ahli tasawuf terkenal yang mendapat julukan "Hujjatul Islam" (Pembela Islam) (Sjadzali,1993:70).

Ayahnya dikenal sebagai orang yang sangat jujur, hidup dari usaha mandiri, bertenun kain bulu dan sering berkunjung pada rumah alim ulama, menuntut ilmu dan berbuat jasa kepada mereka. Ia sering berdo'a kepada Allah Swt agar diberikan anak yang pandai dan berilmu. Akan tetapi belum menyaksikan jawaban Allah atas do'anya, beliau meningal dunia pada saat putra idamannya dalam masih usia anak-anak (Zainuddin, 1991:7)

Abu Hamid mendapat pendidikan pertama kali di Thus, di bawah asuhan seorang pendidik dan ahli tasawuf, yakni sahabat karib ayahnya. Yang mana sebelum ayahnya meninggal dunia sudah mewasiatkan untuk menyerahkan Abu Hamid padanya. Setelah mendapat amanah dari sang sahabat maka, sang sufi pun membawa dan mengasuh sang imam ala kehidupan yang ia jalani dalam kesehariannya. Setelah harta peninggalan Abu Hamid habis, maka sang sahabat pun mengirim Abu Hamid kesalah satu madrasah yang ada di tempat tersebut. Di dalam madrasah tersebut, Imam al-Ghazali mempelajari ilmu Fiqih kepada Amad bin Muhammad ar-Razikani dan mempelajari ilmu tasawuf kepada Yusuf an-Nasaj, sampai pada usia 20 tahun.

Kemudian Imam al-Ghazali memasuki sekolah tinggi Nizhamiyah, yang akhirnya ia bertemu dengan Imam 
Harmain, dan beliau mempelajari berbagai ilmu fiqih, mantiq, dan usul fiqih, selain itu juga mempelajari filsafat dari risalah-risalah Ihwanu Shofa karangan Al-Farabi, Ibnu Maskawaih. Sehingga dengan mempelajari ajaranajaran ahli filsafat itu, Imam al-Ghazali dapat menyelami faham-faham Aristoteles dan pemikir Yunani yang lain. Juga ajaran-ajaran Imam Syafi'i Harmalah, Jambab al-Muhasibi (Zainuddin, 1991 :8).

Dalam usia 28 tahun, Imam alGhazali telah menggemparkan kaum sarjana dan ulama dengan kecakapannya yang luar biasa. Di Naisabur ia telah menghidupkan paham Skeptisme yang dianut oleh para sarjana Eropa pada masa berikutnya. Sejak kecil Imam al-Ghazali dikenal sebagai seorang anak yang pecinta ilmu pengetahuan dan penggandrung mencari kebenaran yang hakiki, sekalipun diterpa duka cita. Kemudian pada tahun $483 \mathrm{H} / 1090 \mathrm{M}$, ia diangkat menjadi guru besar di Universitas Nizhamiyah Baghdad. Empat tahun lamanya Imam al-Ghazali mengajar di lembaga kenamaan itu, ia pun masyhur dengan sebutan maha guru, sehingga beliau terhitung salah seorang ilmuan yang sangat disegani, dan ahli hukum yang dikagumi, baik di lingkungan Nizhamiyah, maupun pemerintah Bagdad .

Setelah lebih kurang dua bulan lebih lamanya beliau mengalami krisis rohani beliau meninggalkan kota Baghdad menuju Damaskus, Suria dan disana beliau hidup menyendiri, berkhalwat di Mean atau salah satu sudut Masjid Umayyah. Di sana beliau menyusun karya besarnya, yakni Ihya Ulumiddin dan karya-karya lainnya. Sekitar dua tahun di Damaskus, kemudian beliau menuju Baitul Haram untuk menunaikan ibadah haji pada tahun $489 \mathrm{H}$ dan tinggal di sana beberapa hari (Zainuddin, 1991:30).

Setelah sekitar sepuluh hingga dua belas tahun dalam perantauannya di Damaskus, Baitul Haram, Syam, Hijz, Baitul Maqdis dan Mesir, pada tahun 499 H /1106 M, beliau kembali ke Bagdad. Setelah kembali ke Khurasan dan mengajar di Madrasah Nizhamiyah Naisabur, namun itu tidak bertahan lama disebabkan wafatnya Fakhul Mulk pada tahun $500 \mathrm{H} / 1107 \mathrm{M}$, beliau memutuskan untuk kembali ketanah kelahirannya di Thus dengan mendirikan Madrasah di dekat rumahnya untuk mengajarkan fiqih dan tasawuf, sehingga bertepatan pada hari senin tanggal 14 Jumadil akhir tahun 505 H/ 19 Desember 1111 M beliau wafat dan dikebumikan di pekuburan Thabran. Imam al-Ghazali meninggalkan tiga orang anak perempuan dan satu orang laki-laki bernama Hamid (Zainuddin, 1991 :10).

\section{Perkembangan Spiritual Imam al- Ghazali}

Menurut Dr. Sulaiman Dunya dalam bukunya Al-Haqiqat Pandangan Hidup Imam al-Ghazali, bahwa kehidupan Imam al-Ghazali dibagi menjadi tiga masa, yaitu masa sebelum ragu, masa ragu dan masa mendapat petunjuk dan tenang.

Adapun masa sebelum ragu adalah masa dimana akal sedang berkembang dan berproduksi. Sebab masa itu Imam al-Ghazali masih sedang belajar dan masih belum mencapai tingkat kematangan berpikir. Dalam masa ini Imam al-Ghazali tidak ada ragu sedikitpun terhadap timbangan hakikat. Sebab, beliau pada saat itu memiliki akal, panca indra, dan nash secara lahiriyah. Dan masa pertama ini beliau mengandalkan otaknya dan ilmu pengetahuan yang di milikinya. 
Adapun masa tahap yang kedua adalah masa keraguan. Imam al-Ghazali memberi komentar, bahwa keraguan yang datang dalam keadaan usia beliau masih muda. Di mana masa tersebut adalah masa yang sangat panjang. Karena di mulai dari usaha beliau hingga menjalankan tasawuf, dan mendapat petunjuk.

Yang cukup mengagumkan dari Imam al-Ghazali adalah ketika beliau sedang mengalami keraguan dalam hakikat kebenaran, justru beliau melahirkan karya tulis yang positif tentang hakikat kebenaran dan memberikan pelajaran dengan cara yang positif. Keraguan Imam al-Ghazali juga tertuju pada masalah ilahiyat; seperti tambahan sifat atau tidaknya. Masalah takdir apakah berlaku kepada seluruh makhluk yang ada di bumi ini.

Imam al-Ghazali meski menderita keraguan, beliau masih menganggap akal adalah suatu hal yang sederhana yang bisa dibuat sebagai pegangan untuk mendapatkan ilmu yang sahih. Setelah berpindah dari satu aliran kepada aliran yang lain akhirnya menjatuhkan hatinya pada tasawuf.

Dalam masa khalwat dan menyendiri, Imam al-Ghazali mendapatkan hakikat yang sejak dahulu beliau ingin mencapainya. Hingga akhirnya jiwanya mendapatkan sebuah ketenangan, dan kebingungannya telah lenyap. Sehingga beliau mengatakan bahwa jalan sufiyah adalah jalan yang paling tepat untuk menghilangkan kebingungan (Dunya, $2002: 121$ ).

\section{Karya-karya Imam al-Ghazali}

Al-Ghazali adalah seorang pemikir Islam yang genius yang tingkat intelektualnya sangat tinggi. Dengan dibuktikan dengan banyaknya karyakarya beliau dalam berbagai disiplin ilmu pengetahuan, antara lain: bidang filsafat, ilmu kalam, fiqih, usul fiqih, tafsir, tasawuf, akhlak, dan otobiografinya.

Dalam muqaddimah kitab "Ihya 'Ulumiddin", Dr. Badawi mengatakan bahwa Imam al-Ghazali menulis karyakarya beliau sebanyak 47 kitab yang disusun menurut beberapa kelompok ilmu pengetahuan sebagai berikut: Pertama, Kelompok Filsafat dan Ilmu Kalam, yang meliputi: Maqashid al Falasifah (Tujuan Para Filosof), Tahaput al Falasifah (Kerancauan Para Filosof), Al-Iqtishod fi al I'tiqad (Moderasi Dalam Aqidah), Al-Munqid al-Dhalal (Pembebasan Dari Kesesatan), Al-Maqashidul Asna fi Ma'ani Asmillah Al-Husna (Arti Nama-nama Tuhan Allah Yang Hasan), Faishalut Tafriqah bainal Islam waz Zindiqah (Perbedaan antara Islam dan Zindiq), Al-Qishasul Mustaqim (Jalan untuk Mengatasi Perselisihan Pendapat), Al-Mustadhiri (Penjelasan Penjelasan), Hujjatul Haq (Argumen yang Benar), Mufsihul Khilaffi Usuluddin (Memisahkan Perselisihan dalam Usuluddin), Al-Muntahal fi 'Ilmil Jidal (Tata Cara dalam Ilmu Diskusi), AlMadhnun bin 'Ala Ghairi Ahlihi (Persangkaan pada Bukan Ahlinya), Mahkun Nadhlar (Metodologika), Asraar 'Ilmiddin (Rahasia Ilmu Agama), Al-Arba'in fi Ushuluddin (40 Masalah Agama), Iljamul Awwam 'an 'Ilmil Kalam (Menghalangi Orang Awwam dari Ilmu Kalam), Al-Qulul Jamil Fir Raddi ala man Ghayaral Injil (Kata yang Baik untuk Orang-orang yang Mengubah Injil), Mi'yarul'Ilmi (Timbangan Ilmu), Al Intishar (Rahasia-rahasia Alam) dan Isbatun Nadlar (Pemantan Logika).

Kedua, Kelompok Ilmu Fiqih dan Ushul Fiqh, yang meliputi: Al-Basith (Pembahasan yang Mendalam), AlWasith (Perantara), Al-Wajiz (Surat Surat Wasiat), Khulashatul Mukhtashar (Inti Ringkasan Karangan), Al Mustasyifa (Pilihan), Al-Mankhul (Adat Kebiasaan), 
Syifakhul 'Alil fi Qiyas Was Ta'lil (Penyembuh yang Baik dalam qiyas dan Ta'lil) dan Az-dzari'ah ila Makarimis Syaria'ah (Jalan kepada Kemulian Syari'ah).

Ketiga, Kelompok Ilmu Akhlak dan Tasawuf, yang meliputi: Ihya 'Ulumiddin (Menghidupkan Kembali Ilmu-ilmu Agama), Mizanul Amal (Timbangan Amal), Kimiyaus Sa'adah (Kimia Kebahagian), Miskatul Anwar (Relungrelung Cahaya), Minhajul 'Abidin (Pedoman Beribadah), Ad-Dararul Fakhirah fi Kasyfi Ulumil Akhirah (Mutiara Penyingkap Ilmu Akhirat), Al'Ainis fil Wahda (Lembut-lembut dalam Kesatuan), Al-Qurbah Ilallahi Azza Wa Jalla (Mendekatkan Diri Kepada Allah), Akhlah al-Abrar Wanajat minal Asrar (Akhlak yang Luhur Menyelamatkan dari Keburukan), Bidayatul Hidayah (Permulaan Mencapai Petunjuk), AlMabadi wal Ghayyah (Permulaan dan Tujuan), Talbis al-Iblis (Tipu daya Iblis), Nasihat al-Mulk (Nasihat untuk Rajaraja), Al-'Ulum Al-Laduniyyah (Ilmu-ilmu Laduni), Al-Risalah al-Qudsiyah (Risalah Suci), Al-Ma'khadz (Tempat Pengambilan) dan Al-Amali (Kemulian);

Keempat, Kelompok Ilmu Tafsir yang meliputi: Yaaquutut Ta'wil fi Tafsirit Tanzil (Metodologi Ta'wil di dalam Tafsir Diturunkan, terdiri 40 jilid) dan Jawahir Al-Qur'an (Rahasia yang Terkandung dalam Al-Qur'an).

Karya-karya besar Imam alGhazali tersebutlah yang kemudia dijadikan referensi dalam pembuatan karya-karya ilmiah di berbagai lembaga pendidikan yang ada di penjuru dunia (Zainuddin,19-21).

\section{Buya Hamka \\ Riwayat Hidup}

Haji Abdul Karim bin Abdul Malik Amrullah (dikenal dengan nama Hamka) dilahirkan di Sungai Batang, Maninjau,
Sumatera Barat pada Ahad 16 Februari 1908 dari keluarga yang taat beragama. Ayahnya adalah Abdul Karim Amrullah atau sering disebut Haji rasul, seorang ulama yang pernah mendalami Islam di Makkah dan pelopor kaum mudo dan tokoh Muhammadiyah Minangkabau. Sementara ibunya bernama Siti Shafiyah Tandjung (Hamka, 1982: 55).

Waktu Hamka dilahirkan, Haji Rasul dengan spontan mengucapkan "sepuluh tahun". Kemudian mertuanya bertanya tentang maksudnya dengan kata-kata "sepuluh tahun", lalu beliau menjawab, sepuluh tahun ia akan dikirim belajar ke Makkah, supaya suatu hari ia akan menjadi orang yang alim seperti aku, seperti kakeknya, dan seperti kakek-kakeknya dulu" (Hamka, 1982: 2).

Sejak kecil, Buya Hamka menerima dasar-dasar agama dan belajar membaca Al-Quran dari ayahnya. Ketika usia 6 tahun, ia dibawa ayahnya ke Padang panjang. Usia 7 tahun masuk ke sekolah, meski akhirnya ia keluar dari sekolah itu setelah 3 tahun belajar, dan malah belajar mengaji dengan ayahnya sampai khatam. Sejak Zainudin Labai elYunusi mendirikan sekolah Diniyah di Pasar Usang Padang panjang, Buya Hamka lalu dimasukkan ayahnya kesekolah ini. Pagi hari Buya Hamka pergi kesekolah desa dan sore hari pergi mengaji ke sekolah Diniyah, dan pada malam hari berada disurau dengan teman-temannya. Seperti itulah kegiatan rutinitas yang selalu dilaluinya. Aktifitas yang begitu monoton membuat Buya Hamka jenuh. Dengan rutinitas yang bagi Buya Hamka cukup membosankan, tidak ayal memancing prilaku menyimpang dalam pertumbuhan Buya Hamka, sehingga dalam menghilangkan kebosanannya sejak kecil ia senang nonton film. Bahkan karena hobinya ini, ia pernah diam-diam membohongi guru ngajinya karena ingin menonton Film 
Eddie Polo dan Marie Walcamp. Kebiasaan menonton film ini berlanjut terus, dan kerapkali ia mendapat inspirasi menulis karya-karya sastra dari menonton film ini. Hal ini dibenarkan oleh A.R. Sutan Mansur, orang yang sangat berpengaruh dalam pertumbuhan pribadi Hamka sebagai seorang muballigh (Hamka, 1966: 21).

Selanjutnya pada tahun 1918, di saat Buya Hamka sudah dikhitan di kampung halamannya Maninjau dan di waktu yang sama pula ayahnya Syeikh Abdul Karim Amrullah, kembali dari tanah Jawa. Kemudian di surau Jembatan Besi, tempat Syeikh Abdul Karim Amrullah memberikan proses pendidikan agama dengan metode lama, dirobah menjadi madrasah yang kemudian dikenal dengan Thawalib School. Tentunya dengan keinginan kelak anaknya jadi ulama sesuai dengan harapannya. Syeikh Abdul Karim Amrullah memasukkan Buya Hamka ke Thawalib School yang diiringi Buya Hamka harus berhenti dari sekolah Desa.

Dalam perkembangan awalnya Thawalib School ini masih belum mampu melepaskan diri dari cara-cara lama dalam proses pembelajaran agama. Kendatipun demikian bagian dari perubahan sudah mulai tampak mewarnai lembaga pendidikan ini. Malah menurut Mahmud Yunus, Surau Jembatan Besi yang sejak dulu memberikan pelajaran agama dengan pola lama, merupakan surau pertama yang mempergunakan system klassikal. (Yunus, 1985: 73). Sekalipun sistem yang menerapkan menghafal ini yang membuat Buya Hamka cepat bosan dan memusingkan kepalanya sendiri.

Kondisi dengan pola belajar seperti di atas tidak menarik bagi Buya Hamka, mengakibatkan keseriusannya untuk belajar tidak tumbuh dari dalam hatinya, namun terpaksa dari kehendak ayahnya. Keadaan inilah yang membuat Buya Hamka betah berada di perpustakaan umum milik Zainuddin Labai el-Yunusi dan Bagindo Sinaro. Buya Hamka menjadi asik di perpustakaan ini mendalami buku-buku cerita dan sejarah. Perpustakaan tersebut yang diberi julukan dengan nama Zainaro, menumbuhkan semangat tertentu bagi Buya Hamka. Tekanan hati yang dirasakannya seolah mendapat tempat pelarian di perpustakaan ini. Ide yang polos dari seorang anak-anak dapat berkembang dan tumbuh, namun seiring dengan pertumbuhan idenya itu, tidak serta merta mendapat dukungan dari ayahnya, sampai ayahnya pernah mengucapkan kata "Apakah engkau akan menjadi orang alim atau hanya akan menjadi tukang cerita", kritikan ini ia dapatkan ketika tertangkap basah sedang asik membaca di perpustakaan.

Di usianya yang ke 12 tahun, adalah merupakan goncangan jiwanya yang cukup berat. Hal demikian dikarenakan perceraian ayah dan ibunya yang tidak terbantahkan. Karena demikianlah suatu kemustian menurut adat. Suatu hal yang sangat mungkin bahwa peristiwa ini yang kemudian dapat membentuk sikap Buya Hamka yang memandang praktek adat tidak sesuai ajaran agama Islam. Adat, terutama adat kawin cerai, yang tidak lapuk oleh hujan dan tidak lekang oleh panas, menurut Buya Hamka, "Seumpama batu yang sudah berlumut sudah masanya untuk disimpan" (Hamka, 1982:36-37).

Setiap ketetapan yang dijalankan di dalam adat, serta terlalu mudahnya dalam menafsirkan tentang kebolehan untuk berpoligami, kendatipun berdalih merupakan ajaran Islam dan sudah tertanam dalam pemikiran orang Minangkabau. Pemahaman yang demikian, akan memberikan kemungkinan yang luas bagi para ulama, sebagai 
seorang yang terpandang di tengah masyarakat, untuk mendapatkan pembenaran melakukan kawin cerai dengan berulang-ulang. Kenyataan ini pula yang didapatkan oleh Buya Hamka dalam keluarganya, yang berujung pada si Hamka kecil, menjadi anak "tinggal", yang pada gilirannya dapat membentuk "kenakalan" dalam keseharian Buya Hamka (Hamka, 1966: 37).

Kenyataan yang demikian membuat Buya Hamka merasa ingin jauh dari kehidupan ayahnya. Keinginan yang besar untuk pergi ke tanah Jawa, sebagai akibat dari pemahamannya yang di dapat sebagai bentuk informasi di perpustakaan Zainaro. Buya Hamka mengambil keputusan yang boleh dibilang nekat, berangkat ke tanah Jawa seorang diri. Tapi kenyataan tidak semulus yang dibayangkan, pelariannya terhenti di Bengkulu karena ia terkena penyakit cacar. Sampai dua bulan lamanya Buya Hamka berada di pembaringan. Setelah sembuh ia kembali pulang ke Padang Panjang dengan tubuh dan wajah dipenuhi bekas cacar. Kegagalan ini tidak membuat Buya Hamka putus asa, setahun kemudian, tanpa dapat dihalangi oleh ayahnya, Buya Hamka berangkat kembali untuk yang kedua kalinya menuju tanah Jawa pada tahun 1924.

Buya Hamka menetap di tanah Jawa relatif singkat, kurang lebih dari satu tahun, menurut Buya Hamka sendiri telah mampu memberikan "semangat baru" baginya dalam mempelajari agama Islam. Musafir dalam rantau dalam pencarian ilmu ia mulai dari kota Yogyakarta, dimana kota tersebut merupakan tempat lahirnya organisasi Muhammadiyah. Melalui Ja'far Amrullah, pamannya, Buya Hamka kemudian memperoleh kesempatan mengikuti kursus-kursus yang diselenggarakan oleh Muhammadiyah dan Syarikat Islam.
Dalam perjalanannya ia juga bertemu dengan Hos Cokroaminoto dan menimba ilmu tentang gerakan Islam modern kepada Hos Cokroaminoto, Ki Bagus Hadikusumo, RM Soerjopranoto, dan K.H. Fakhrudin. Saat itu, Buya Hamka mengikuti berbagai diskusi dan training pergerakan Islam di Abdi Dharmo Pakualaman, Yogyakarta. Tidak hanya sampai disitu, Buya Hamka juga mendengar langsung ceramahnya tentang Islam dan Sosialisme. Disamping itu ia berkesempatan bertemu dengan beberapa tokoh penting lainnya, seperti Haji Fakhruddin dan Syamsul Rijal (Hamka, 1982: 56). Dalam perantauannya mengisyaratkan bahwa Yogyakarta mempunyai makna tersendiri dalam pertumbuhan dan perkembangan pemikiran Buya Hamka sebagai seorang pejuang dan penganjur Islam. Dimana kota tersebut telah memberikan sesuatu dalam mendorong kesadaran keagamaan Buya Hamka dan memperkokoh semangat kepemudaannya, meskipun belum dapat dilepaskannya secara keseluruhan sifat kekanak-kanakannya. Namun ia sudah dipandang sebagai pemuka diantara rekan-rekannya. Ia sendiri menyebutkan bahwa di Yogyakarta Islam itu sebagai sesuatu yang hidup, yang mengedepankan kedinamisan dalam pendirian dan perjuangan.

\section{Aktivitas Hamka}

Setelah malang-melintang musafir dan belajar di Yogyakarta, semangat keIslaman yang tertanam dalam hatinya bermanifestasi dengan bentuk gerakangerakan sosial dan politik serta agama di Yogyakarta, dapat membuat Buya Hamka terlarut di dalamnya. Sebagai mana yang diceritakannya sendiri, ia pernah ikut serta dalam keramaian peringatan maulid Nabi yang sangat meriah, yang dalam perhelatan besar itu 
berbaris sambil mengibarkan benderabendera yang bertuliskan "Al-Islam" yang berwarna hijau (Hamka, 1979: 101).

Tumbuhnya kesadaran baru dalam memandang wajah Islam yang diperolehnya di Yogyakarta, kemudian beriring dengan pengukuhannya di saat ia berada di Pekalongan, selama lebih kurang enam bulan. Dari kedekatannya dengan menantu ayahnya AR Sutan Mansur yang menetap di Pekalongan, dapat memberinya ruh perjuangan dalam mempertahankan kemuliaan hidup. Sejak saat itu Buya Hamka meyakinkan dirinya untuk aktualisasi hidupnya sebagai seorang pemegang amanah Allah dan penyampai risalah agama Islam. Dalam usia yang terbilang muda, 17 tahun, Hamka mampu berpidato dimana-mana dengan landasan gelora dari semangatnya yang baru.

Dengan memiliki modal intelektual dan semangat pergerakan seperti yang digambarkan di atas, Buya Hamka kembali ke Minangkabau. Sejak itu ia mulai memperbaiki dan menyempurnakan arah yang dipilihnya sebagai seorang tokoh sekaligus ulama dalam arah perkembangan pemikiran dan pergerakan Islam di Indonesia yang semakin pesat. Dalam usianya yang masih 17 tahun di waktu kembali ke Minangkabau dalam perjalanannya dari tanah Jawa, seiring dengan waktu Buya Hamka pun telah tumbuh menjadi seorang yang dewasa, di tengah-tengah lingkungannya. Ia mulai berani untuk tampil berpidato, bertabligh di kalangan masyarakat Minangkabau yang telah melahirkan dan membesarkannya. Ia pun mulai membuka kursus pidato bagi teman-teman sebayanya di Surau Jembatan Besi. Kemampuan dasar alami yang dimiliki oleh Buya Hamka dalam mengolah dan menyusun kata-kata, baik dalam berorasi maupun dalam menulis, mampu mengantarkan Buya Hamka pada tempat yang diistimewakan di kalangan teman-temannya. Ia kreatif dalam membukukan serta menyusun ulang pidato teman-temannya dan kemudian diterbitkan dalam bentuk majalah yang dipimpinnya yang diberi nama Khatibul Ummah (Hamka, 1966: 57).

Dalam kenyataannya jalan yang mulai perlahan diretas oleh Buya Hamka, bukanlah tanpa hambatan dan tantangan. Bahkan ungkapan yang tidak bersahabat itupun datang dari temantemannya dan kalangan masyarakat Minangkabau, yang dianggap memiliki latar belakang pendidikan dan pemahaman keagamaannya yang didasari oleh kefasihan ilmu Nahwu dan Sharaf, mereka beranggapan bahwa Buya Hamka tidak mempunyai kelebihan. Seperti yang diungkapkan mereka bahwa Buya Hamka hanyalah seorang "tukang pidato" saja. Buya Hamka bukanlah ahli agama atau alim, bahkan ia tidak mempunyai modal yang kuat sebagai seorang ulama, yakni tidak dapat memahami secara mendalam ilmu Bahasa Arab.

Dalam anggapan masyarakat bahwa Buya Hamka belum memiliki modal dasar yang harus dikuasai layaknya sebagai seorang ulama. Menurut masyarakat Minangkabau, Buya Hamka memang pandai, namun kemahirannya seperti yang disebutkan oleh ayahnya, "cuma pandai menghafal syair, bercerita masalah sejarah, seperti seekor burung beo". Pada kenyataannya ungkapan miring dalam bentuk kritikan yang dilontarkan oleh masyarakat menimbulkan pukulan tersendiri dalam semangat Buya Hamka. Dimana kenangan pahit diwaktu ia masih kecil dalam perasaannya seakan terulang kembali. Apalagi disaat Buya Hamka tahu bahwa gadis tunangannya telah menikah dengan pemuda lain. Pukulan 
kritikan yang menimbulkan rasa traumanya dimasa kecil menjadi salah satu faktor Buya Hamka membulatkan tekatnya untuk mengambil sebuah keputusan untuk pergi ke Makkah, boleh dikatakan suatu bentuk tempat pelarian yang kedua kalinya atas sikap kurang pedulinya keluarga dan ayahnya terhadap mental dan nasib Buya Hamka.

Dengan memulai hidup di Kota Makkah, aktivitasnya sebagai seorang pergerakan yang telah tertanam kokoh dalam jiwanya semenjak tinggal di Yogyakarta, membuat Buya Hamka tidak tinggal diam. Semenjak ia berangkat dari tanah air pada bulan Februari 1927, menjelang pelaksanaan ibadah haji, Buya Hamka bersama dengan beberapa calon jamaah haji lainnya sempat mendirikan sebuah wadah organisasi yang bernama Persatuan Hindia Timur. Organisasian ini mempunyai tujuan untuk memberikan pelajaran agama, terutama manasik haji, terhadap para calon jamaah haji dari Indonesia.

Dilain hal, dalam mewujudkan keinginannya besama teman-teman di organisasi dalam memberikan pelajaran agama dalam manasik haji, harus mendapatkan izin dari Amir Faisal. Dengan kemampuan berbahasa Arab yang pas-pasan, Buya Hamka memberanikan diri untuk tampil sebagai ketua delegasi untuk menghadapi Amir tersebut (Hamka, 1979: 126). Ini merupakan sebuah keberanian yang sangat langka di kalangan calon jamaah haji asal Indonesia.

Dilain masa, Buya Hamkapun telah menyelesaikan berbagai macam aktivitasnya di kota Makkah. Tentu waktunya untuk pulang ke kampung halaman, dengan menyandang gelar, suatu nama yang menjadi sebuah legitimasi sebagai seorang ulama dalam pandangan masyarakat Minangkabau.
Buya Hamka pun seolah memberikan penjelasan bahwa kehadirannya ditengah berbagai macam perkembangan pemikiran keagamaan di Minangkabau. Sebelumnya Buya Hamka dianggap tidak mempunyai kemampuan yang layak, namun kemudian beliau sudah menjadi seorang yang siap untuk menggantikan keulamaan ayahnya, yakni Syeikhk Abdul Karim Amrullah.

Meskipun berbekal dengan harapan masyarakat dan keluarga, bahwa Buya Hamka siap dalam menggantikan keulamaan ayahnya. Namun hal tersebut tidak dapat mengubah arah keinginan yang sudah tertanam dalam jiwa Buya Hamka sebagai seorang pergerakan. Dan dalam hal itu, beberapa waktu setelah ia menikah dengan Siti Rahmah, ia mulai aktif sebagai pengurus Muhammadiyah Cabang Padang Panjang. Bahkan tidak hanya sampai disitu aktivitasnya, iapun dipercaya sebagai pimpinan sekolah yang diberi nama Tabligh School.

Secara berangsur-ansur, pengukuhan Buya Hamka sebagai tokoh dan penyampai ajaran agama Islam secara pasti ia mantapkan. Pada tahun 1929 Buya Hamka menjadi guru agama di Padang Panjang. Dan pada tahun 1934 beliau diangkat menjadi anggota tetap Majlis Konsul Muhammadiyah Sumatera Tengah.

Setelah Buya Hamka pulang dari Makasar, iapun mendirikan Kulliyatul Muballighin di Padang Panjang, disamping beliau aktif menjadi seorang muballigh. Kemudian pada tahun 1936 Buya Hamka pindah ke Medan. Di kota ini Buya Hamka berkiprah bersama dengan M. Yunan Nasution dan Sami menerbitkan majalah Pedoman Masyarakat, menurut M. Yunan Nasution penerbitan majalah ini dapat memberikan andil yang tidak sedikit bagi perkembangan pengarangan dan pujangga Hamka di masa akan datang. 
Secara berangsur karya-karyanya pun mulai diterbitkan, seperti Di Bawah Lindungan Ka'bah, Pedoman Muballigh Islam, Teggelamnya Kapal Van Der Wijk, Tashauf Moderen, Filsafat Hidup, Merantau ke Deli dan Tuan Direktur.

Di waktu tentara Jepang berhasil mendarat di kota Medan pada tahun 1942, kehadiran Jepang tentunya berdampak terhadap aktivitas masyarakat, termasuk didalamnya kegiatan Buya Hamka. Salah satu contohnya majalah Pedoman Masyarakat dihanguskan. Bendera kebanggaan Indonesiapun tidak boleh dinaikkan lagi. Hampir semua masyarakat kecewa dengan keadaan ini. Namun walaupun demikian, Buya Hamka masih mendapat kedudukan yang istimewa dalam pemerintahan Jepang. Sebagai tokoh Muhammadiyah dan pemuka masyarakat, Buya Hamka diangkat sebagai anggota Syu Sangi Kai, Dewan Perwakilan Rakyat yakni pada tahun 1944. Dalam kedudukannya ini, Buya Hamka diminta pertimbangan oleh pemerintah Jepang untuk mengatasi masalah-masalah yang timbul dari kalangan ummat Islam. Posisi dapat menempatkan Buya Hamka sebagai "anak emas" Jepang. Tentunya tidak dapat untuk dipungkiri keadaan ini membuat Buya Hamka menjadi tersisih dalam pandangan masyarakat medan, terutama terkait organisasinya Muhammadiyah. Kritikan yang bernada sumbang sering ia terima, sehingga membuat Buya Hamka membuat satu istilah dengan keadaan ini dengan sebutan "lari malam" dari kota Medan.

Akhirnya pada tahun 1945, Hamka meninggalkan kota Medan kemudian ia menetap kembali di kota Padang Panjang. Kedatangan Buya Hamka di Padang Panjang disambut gembira oleh sahabat-sahabatnya, dan kepemimpinan Kulliyatul Muballighin kembali diserahkan kembali kepada Buya
Hamka. Konsentrasinya sekarang terpusat terhadap pengelolaan sekolah ini, peluang untuk memulai kembali menulis karya-karya yang digemari oleh masyarakat berangsur ia tekuni. Sehingga pada masa ini sampai terbit buku-bukunya; Negara Islam, Islam dan Demokrasi, Revolusi Pikiran, Revolusi Agama, Adat Minang Kabau Menghadapi Revolusi dan dari Lembah Cita-cita.

Dalam kurun waktu yang tidak lama semenjak kepulangannya ke Padang Panjang, Buya Hamka pun terpilih menjadi ketua Muhammadiyah dalam Konprensi Muhammadiyah di Padang Panjang pada tahun 1946. Kedudukannya sebagai ketua Muhammadiyah membuat Buya Hamka memperoleh banyak kesempatan untuk berkeliling Sumatera Barat, dengan sekaligus mempunyai tujuan untuk merangsang cabang-cabang Muhammadiyah untuk meningkatkan kegiatan penyiaran Islam dalam rangka meneguhkan keutuhan dan persatuan bangsa. Keadaan seperti ini sangat menguntungkan bagi Buya Hamka, sehingga kebolehannya sebagai penulis dan penceramah semakin dikenal. Buya Hamka dipandang sebagai pemimpin agama dan juga sebagai pejuang kebangsaan.

Ketika agresi Belanda yang pertama meletus pada tahun 1947, Wali Kota Padang Bagindo Aziz Chan wafat ditembak oleh Belanda, memicu bangkitnya perlawanan bersenjata di Negeri Minangkabau untuk mengusir penjajah Belanda. Maka untuk keperluan membangkitkan semangat perjuangan rakyat Sumatera Barat, dibentuklah sebuah badan yang dikenal dengan nama Front Pertahanan Nasional (FPN). Buya Hamka diberi kepercayaan untuk mengetuai dari sekretaris FPN tersebut.

Setelah tercapainya gencatan senjata dengan pihak Belanda pada 
tahun 1949 dan mulailah disusun pemerintahan Republik Indonesia untuk Sumatera Tengah, Buya Hamka sadar bahwa pekerjaan yang digagas itu bukanlah hal yang mudah, karena sudah mengarah kepada bidang pemerintahan. Sementara ia hanyalah seorang penulis dan pujangga, disamping sebagai tokoh agama tengah-tengah masyarakat. Namun ia memilih kegiatan itu dengan penuh keyakinan, dan dengan kesungguhannya Buya Hamka terlihat dapat bertahan dengan aktivitasnya itu. Oleh karena itu Buya Hamka berkeyakinan bahwa untuk memudahkan kegiatan-kegiatannya sebagai seorang muballigh dan penulis Islam lalu ia memutuskan untuk mencoba pindah ke Jakarta. Pada tanggal 18 Desember 1949, dengan semangat dan keyakinannya Buya Hamka meninggalkan Minangkabau menuju kota Metropolitan. (Hamka, 1979: 292).

Ternyata di tempat barunya kota Jakarta, dapat menawarkan kepadanya banyak kemungkinan. Setelah ia berada di ibu Kota beberapa waktu, ia diterima sebagai anggota koresponden surat kabar Merdeka dan majalah Pemandangan. Autobiografinya KenangKenangan Hidup diwaktu ini juga Buya Hamka mulai menuliskannya. Kota Jakarta juga memberikan kesempatan kepada Buya Hamka pilihan yang baru, yakni kesempatan untuk menjadi seorang politik praktis. Buya Hamka memilih untuk bergabung dengan partai politik Islam yaitu Masyumi.

Terpilihnya Buya Hamka menjadi anggota konstituante dari partai Masyumi diwaktu berlangsungnya pemilihan umum di Indonesia pada tahun 1955, adalah sebagai bukti bahwa kegiatan politik praktis tidaklah sampai menggangu aktivitasnya sebagai seorang muballigh, penulis dan sekaligus pejuang Islam. Karena melalui konstituante Buya Hamka dapat dengan gigih memperjuangkan dan mengedepankan kepentingan Islam.

Buya Hamka memiliki pandangan tersendiri tentang Islam di Indonesia, menurutnya Islam adalah pondasi dan falasafah hidup bangsa Indonesia yang sudah tertanam kokoh dalam kebudayaan tradisional. Bahkan disamping itu, Buya Hamka berpendapat, kedudukan Islam begitu kuat berakar dalam perkembangan kebudayaan Indonesia, malah melebihi kesakralan Pancasila yang menjadi motor revolusi dalam merebut dan mempertahankan kemerdekaan Indonesia. Pada akhirnya tidak dapat disangkal bahwa perjuangannya untuk mengedepankan pembelaan terhadap agama Islam belum membuahkan hasil, namun ia sudah menunjukkan kegigihannya untuk menegakkan Islam.

Undangan Amerika Serikat pada Buya Hamka pada tahun 1952, saat itu Hamka menjabat di penasehat Departemen Agama. Sejak Buya Hamka berkunjung ke Amerika Serikat, Hamka mempunyai pandangan yang lebih luas dan terbuka terhadap bangsa diluar Islam. Sepulangnya Hamka menerbitkan sebuah buku yang mengisahkan tentang perjalanannya dengan judul Empat Bulan di Amerika sebanyak dua jilid. Setelah itu aktivitas Buya Hamka semakin banyak, dengan ditunjuknya Hamka menjadi anggota missi kebudayaan ke Muangthai pada tahun 1953, berselang satu tahun Buya Hamka mewakili Departemen Agama untuk menghadiri peringatan mangkatnya Budha ke 2500 di Burma pada tahun 1954, dilanjutkan dengan menghadiri Konprensi Islam di Lahore tahun 1958, tidak sampai disitu kegiatan lawatannya, bahkan ia memenuhi undangan Uneversitas Al-Azhar Kairo dalam rangka memberikan ceramah tentang pengaruh Muhammad Abduh di 
Indonesia. Pada gilirannya penampilan Hamka itu membuahkan hasil gelar Doktor Honorius Causa.

Sebagai seorang tokoh masyarakat dan agama, Buya Hamkapun tidak luput dari hasutan. Ia pernah dituduh menggagas rapat gelap menyusun rencana membunuh presiden Soekarno. Atas tuduhan merencanakan pembunuhan presiden itu, Buya Hamka lalu ditangkap dan dimasukkan kedalam penjara. Didalam tahanan, bakatnya tidak pernah padam, sehingga ia menyelesaikan Tafsir Al-Azhar dan disusul dengan karya yang lain yakni Antara Fakta dan Khayal Tuanku Rao (Hamka, 1974: 13).

Belajar dari pengalaman pahit yang dialami Buya Hamka, seperti yang dijelaskan diatas. Buya Hamkapun mengambil sebuah keputusan untuk memusatkan perhatiannya untuk kegiatan-kegiatan siar Islam. Kemudian ia jadi pimpinan pada majalah Panji Masyarakat dan sekaligus menjadi imam besar Masjid Al-Azhar, Buya Hamka juga sering dipercaya sebagai wakil pemerintahan Indonesia dalam pertemuan-pertemuan Islam Internasional, seperti konfrensi Negaranegara Islam yang dilaksanakan di Rabat pada tahun 1968, kemudian Muktamar Masjid yang digelar di Makkah pada tahun 1971, seminar Tentang Islam dan Peradaban di Kuala Lumpur, dilanjutkan dengan Upacara Peringatan Seratus Tahun Muhammad Iqbal bertempat di Lahore dan mengikuti Konfrensi Ulama di Kairo tahun 1977.

Aktivitas yang begitu banyak yang dilaksanakannya itu dijalani sebagian besar disaat usianya sudah mulai tua, tentu akan berdampak kepada terganggunya kesehatan Buya Hamka sendiri, sehingga Buya Hamka masuk rumah sakit menjelang hari peringatan ulang tahunnnya yang ke-70 tahun, bertepatan pada tanggal 16 Februari 1978. Dengan perawatan yang maksimal tentunya, kesehatan Hamka mulai pulih, lalu Buya Hamka pulang kerumah dan lebih banyak menunggu orang-orang datang kerumahnya untuk bertukar pikiran tentang persoalan kehidupan dan masalah-masalah agama.

Dua tahun menjelang wafatnya, Buya Hamka sejak tahun 1975 menjadi ketua Majelis Ulama Indonesia mengundurkan diri. Sebab dari mundurnya Buya Hamka dari jabatannya adalah perayaan Natal bersama antara Umat Kristen dan penganut Umat lainnya termasuk agama Islam. Sementara pada waktu itu Majelis Ulama Indonesia yang dipimpin oleh Buya Hamka telah mengeluarkan fatwa bahwa haram hukumnya seorang muslim mengikuti perayaan Natal.

Dua bulan setelah Buya Hamka mengundurkan diri dari ketua Majelis Ulama Indonesia, ia kembali masuk rumah sakit akibat serangan jantung yang cukup berat. Lebih kurang satu minggu Buya Hamka dirawat di rumah sakit Pertamina ahli Jakarta Pusat, yang ditangani oleh dokter ahli. Namun usaha yang maksimal yang dilakukan oleh para dokter ahli dengan mengerahkan semua kemampuannya, rupanya Allah berkehendak lain. Pada tanggal 24 Juli 1981 bersamaan dengan tanggal 22 Ramadhan $1401 \mathrm{H}$, ditemani oleh istrinya Khadijah dan beberapa teman dekat serta puteranya Afif Amrullah, Buya Hamka berpulang kerahmatullah dalam usia 73 tahun.

\section{Karya-Karya Buya Hamka}

Sebagai salah seorang tokoh sekaligus ulama yang terkenal, serta politisi, wartawan dan termasuk salah satu tokoh pembaharuan Islam, Buya Hamka termasuk memiliki jadwal yang padat. Walaupun demikian, aktivitas 
menulisnya terus berlanjut bahkan ia dikenal sebagai tokoh intelektual muslim yang produktif. Yaitu dengan banyak menelurkan karya tulis, yang sampai hari ini tetap menjadi bahan bacaan dan pedoman, bahkan rujukan bagi penelitian ilmiah lainnya.

Jika dianalisa, pemikiran Buya Hamka yang menekankan dalam pembahasan guru profesional terdapat pada beberapa literatur, buku yang membahas tentang guru profesional terdapat dalam beberapa karyanya yaitu : Lembaga Budi dan Lembaga Hidup.

\section{Pandangan tentang Guru profesional Pandangan Guru Profesional menurut Imam al-Ghazali}

Maka barang siapa berilmu, beramal dan mengajar, maka dialah yang disebut orang besar dalam alam malakut tinggi. Dia laksana matahari yang menyinarkan cahayanya kepada orang lainnya dan menyinarkan pula kepada dirinya sendiri. Dia laksana kesturi yang membawa keharuman kepada lainnya dan dia sendiripun harum.

Manakala sudah mengajar maka berarti telah melaksanakan pekerjaan besar dan menghadapi bahaya yang tidak kecil. Maka peliharalah segala adab dan tugas-tugasnya, yaitu:

Tugas pertama: mempunyai rasa belas kasihan kepada murid-murid dan memperlakukan mereka sebagai anak sendiri.

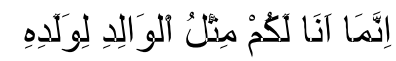

Artinya:"Sesungguhnya aku ini bagimu adalah seumpama seorang ayah bagi anaknya"(H.R. Abu Dawud, An-Nasa-i, Ibnu Majah dan Ibnu Hibban dari Abu Hurairah).

Dengan maksudnya melepaskan murid-muridnya dari api neraka akhirat. Dan itu adalah lebih penting dari usaha ibu-bapak, melepaskan anaknya dari neraka dunia.

Karena itu, hak seorang guru lebih besar dari hak ibu-bapak. Ibu-bapak menjadi sebab lahirnya anak itu dan dapat hidup di dunia yang fana ini. Sedang guru menjadi sebab anak itu memperoleh hidup kekal. Kalau tidak adalah guru, maka apa yang diperoleh si anak itu dari orang tuannya, dapat membawa kepada kebinasaan yang terus menerus.

Guru adalah yang memberikan kegunaan hidup akhirat yang abadi. Yakni guru yang mengajar ilmu akhirat ataupun ilmu pengetahuan duniawi, tetapi dengan tujuan akhirat, tidak dunia.

Sebagaimana hak dari anak-anak seorang ayah, berkasih-kasihan bertolong-tolongan mencapai segala maksud, maka seperti demikianlah kewajiban dari murid-murid seorang guru, berkasih-kasihan dan sayang menyayangi.

Hal itu baru ada, bila tujuan mereka akhirat. Dan kalau tujuannya dunia, maka yang ada tak lain dari berdengki-dengkian dan bermusuhmusuhan.

Sesungguhnya para ulama dan putra-putra akhirat itu adalah orangorang musafir kepada Allah Ta'ala dan berjalan kepadaNya, dari dunia. Tahuntahunnya dan bulan-bulannya adalah tempat-tempat singgahan dalam perjalanan. Sayang menyayangi di perjalanan antara orang-orang yang sama-sama berangkat ke kota, adalah menyebabkan lebih eratnya hubungan dan kasih sayang.

Sebaliknya dalam mengejar kebahagiaan dunia, jalannya tidak lapang. Dari itu senantiasa dalam keadaan sempit berdesak-desakan. Orang yang menyeleweng dengan ilmu pengetahuannya untuk menjadi kepala, 
sesungguhnya telah keluar dari kandungan firman Allah ta'ala:

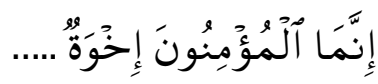

Artinya: " Orang-orang beriman itu Sesungguhnya bersaudara...” (Q.S. AlHuzurat, 49: 10)

Dan masuk kedalam maksud firman Allah Ta'ala:

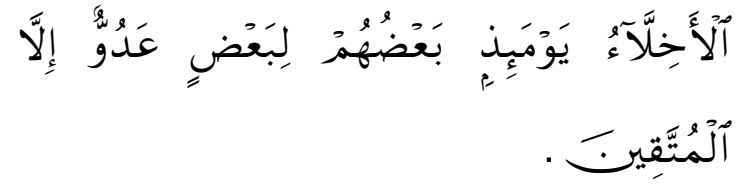

Artinya: " Teman-teman akrab pada hari itu sebagiannya menjadi musuh bagi sebagian yang lain kecuali orang-orang yang bertakwa" (Q.S. Az-Zukhruf, 43: 67).

Tugas kedua: bahwa mengikuti jejak Rasul saw. Maka ia tidak mencari upah, balasan dan terimakasih dengan mengajar itu. Tetapi mengajar karena Allah dan mencari kedekatan diri kepadaNya. Tidak ia melihat bagi dirinya telah menanam budi kepada murid-murid itu, meskipun muridmurid itu harus mengingati budi baik orang kepadanya.

Tetapi guru itu harus memandang bahwa dia telah berbuat suatu perbuatan yang baik, karena telah mendidik jiwa anak-anak itu. Supaya hatinya dekat kepada Allah Ta'ala dengan menanamkan ilmu pengetahuan padanya. Padahal pahala yang anda peroleh dari mengajar itu, pada Allah Ta'ala lebih banyak dari pahala yang diperoleh oleh murid. Dan kalaulah tak ada murid yang belajar, maka anda tidak akan memperoleh pahala itu.

Dari itu, janganlah diharap pahala selain dari Allah Ta'ala, seperti firmanNya:

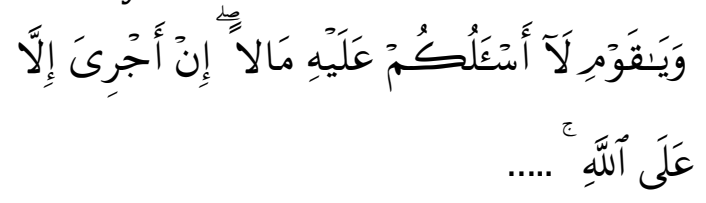

Artinya: "Dan (dia berkata): "Hai kaumku, aku tiada meminta harta benda kepada kamu (sebagai upah) bagi seruanku. Upahku hanyalah dari Allah.. " (Q.S. Huud, 11: 29).

Harta dan isi dunia adalah menjadi pesuruh badan kita. Badan menjadi kendaraan dan tunggangan jiwa. Yang dikhidmati ialah ilmu pengetahuan. Karena dengan ilmu pengetahuanlah, jiwa itu mulia.

Pendek kata, kelebihan dan kenikmatan pula bagi seorang guru. Maka, bagaimana pun caranya urusan agama sampai kepada suatu kaum, yang mendakwakan dengan ilmu yang ada padanya, baik ilmu fiqih maupun ilmu kalam, baik memberi pelajaran dalam ilmu yang dua tadi atau lainnya, adalah untuk mendekatkan diri kepada Allah Ta'ala.

Kemudian, apabila ada guru yang mengharapkan dari muridnya bantuan pada tiap-tiap malapetaka, memberi pertolongan kepadanya, memusuhi musuhnya, bangun memenuhi keperluan hidupnya dan duduk bersimpuh dihadapannya. Apabila murid itu tidak melaksanakan, maka dia memberontak dan muridnya itu menjadi musuhnya yang terbesar.

Ibarat sebuah nasehat yang menyebutkan, "Alangkah kotornya orang berilmu, yang rela untuk dirinya kedudukan. Kemudian, ia bergembira untuk itu. Kemudian, berpura-pura dan tidak malu mengatakan: maksudku dengan mengajar ialah menyiarkan ilmu pengetahuan, untuk mendekatkan diri kepada Allah dan menolong agamaNya." Hal ini ibarat sebenar-benar penipuan yang dilakukan oleh seorang pengajar.

Tugas ketiga: bahwa tidak meninggalkan nasehat sedikitpun kepada yang demikian itu, ialah dengan melarangnya mempelajari suatu tingkat, sebelum berhak pada tingkat itu. Dan belajar ilmu yang tersembunyi, sebelum 
selesai ilmu yang terang. Kemudian menjelaskan kepadanya bahwa maksud dengan menuntut ilmu itu, ialah mendekatkan diri kepada Allah Ta'ala. Bukan karena keinginan menjadi kepala, kemegahan dan perlombaan.

Tugas keempat: yaitu termasuk yang halus-halus dari mengajar, bahwa guru menghardik muridnya dari berperangai jahat dengan cara sindiran selama mungkin dan tidak dengan cara terus terang. Dan dengan cara kasih sayang, tidak dengan cara mengejek. Sebab, kalau dengan cara terus terang, merusakkan takut murid kepada guru. Dan mengakibatkan dia berani menentang dan suka meneruskan sifat yang jahat itu. Nabi saw. Selaku mursyid segala guru, pernah bersabda:

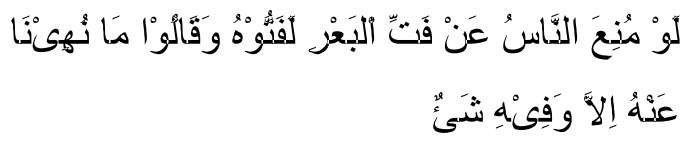

Artinya: "Jikalau manusia itu dilarang dari menghancurkan taik unta, maka akan dihancurkannya dengan mengatakan: kita tidak dilarang dari perbuatan itu kalau tak ada apa-apanya" (walau menurut Al-Iraqi, dia tidak pernah menjumpai hadist ini).

Keadaan yang tersebut tadi, mengingatkan kita pada kisah Adam dan Hawa as. Serta larangan yang ditujukan kepada keduanya. Dan tidaklah kisah itu diterangkan kepadamu untuk menjadi buah pembicaraan di malam hari. Tetapi, untuk engkau sadari atas jalan ibarat.

Juga dengan sindiran itu, membawa kepada jiwa utama dan hati suci, untuk memahami tujuan dari sindiran itu. Maka dengan keinginan memperhatikan maksud dari sindiran itu, karena ingin mengetahuinya, tahulah dia bahwa hal itu tidak boleh lenyap dari perhatiannya.
Tugas kelima: seorang guru yang bertanggung jawab pada salah satu mata pelajaran, tidak boleh melecehkan mata pelajaran lain dihadapan muridnya. Seumpama guru bahasa, biasanya melecehkan ilmu fiqih. Guru fiqih melecehkan ilmu hadits dan tafsir dengan sindiran, bahwa ilmu hadits dan tafsir itu adalah semata-mata menyalin dan mendengar. Cara yang demikian, adalah cara orang yang lemah, tidak memerlukan pikiran padanya. Guru ilmu kalam memandang sepi kepada ilmu fiqih dengan mengatakan, bahwa ilmu fiqih itu membicarakan soal furu'. Diantara lain memperkatakan tentang kain kotor wanita. Maka apakah artinya itu, dibandingkan dengan memperkatakan tentang sifat Tuhan Yang Maha Pengasih?

Inilah budi pekerti yang tercela pada para guru yang harus dijauhkan! Sebaliknya, yang wajar hendaklah seorang guru yang bertanggung jawab suatu mata pelajaran, membuka jalan seluasluasnya kepada muridnya untuk mempelajari mata pelajaran yang lain. Kalau dia bertanggung jawab dalam beberapa ilmu pengetahuan, maka hendaklah menjaga kemajuan simurid dari setingkat ke setingkat!

Tugas keenam: guru harus menyingkatkan pelajaran menurut tenaga pemahaman si murid. Jangan diajarka pelajaran yang belum sampai otaknya kesana. Nanti ia lari atau otaknya tumpul.

Perhatikanlah sabda Nabi saw:

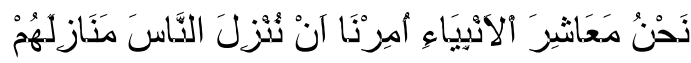

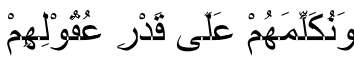

Artinya: "Kami para nabi disuruh menempatkan masing-masing orang pada tempatnya dan berbicara dengan mereka menurut tingkat 
pemikirannya" (dirawikan hadis ini pada sebagian dari Abi Bakar bin AsySyukhair dari Umar dan pada Abi Dawud dari A'isyah).

Kembangkanlah kepada murid itu sesuatu pengetahuan yang mendalam, apabila diketahui bahwa dia telah dapat memahaminya sendiri.

Bersabda Nabi saw:

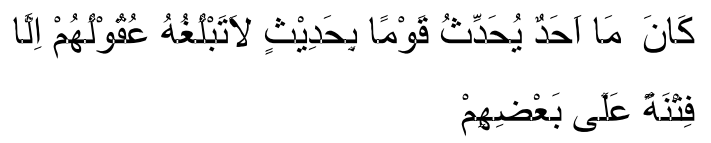

Artinya: "Apabila seseorang berbicara kepada suatu golongan tentang persoalan yang belum sampai otaknya kesana, maka ia menjadi fitnah kepada sebahagian dari mereka"(Hadits ini, ada kata-katanya dari Al-Uqaili dan Abu Na'im dari Ibnu Abbas, dengan isnad dlaif).

Berkata Ali ra. sambil menunjuk kepada dadanya: "disini terkumpul banyak ilmu pengetahuan, sekiranya dapatlah saya peroleh orang-orang yang menerimanya".

Benarlah ucapan beliau itu. Dada orang-orang baik (al-abrar) adalah kuburan ilmu pengetahuan yang tinggitinggi (al-asrar). Dari itu, tidak wajarlah bagi seorang yang berilmu, menyiarkan seluruh ilmu pengetahuannya kepada orang. Hal ini, apabila dapat dipahami oleh yang belajar dan ia belum dapat mengambil faedah dengan ilmunya. Maka betapa pula terhadap orang yang tidak dapat memahaminya? Berkata Isa as: "Janganlah engkau gantungkan mutiara pada leher babi".

Ilmu hikmah adalah lebih mulia dari mutiara. Orang yang tidak suka kepada ilmu hikmah, adalah lebih jahat dari babi. Dari itu dikatakan: sukatlah bagi masing-masing orang, menurut ukuran akalnya. Dan timbanglah bagi masing-masing orang itu dengan timbangan pahamnya, sehingga selamat dan bermanfaat. Kalau tidak ada pemahaman, maka terjadilah pertentangan karena timbangan akal berlebih kurang (salah pengertian = misunderstanding).

Ditanyakan setangah ulama tentang suatu hal. Beliau tidak menjawab, lalu penanya itu bertanya lagi: tidakkah tuan mendengar sabda Nabi saw:

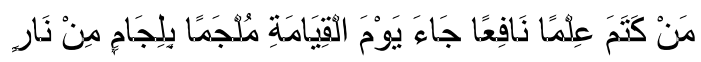

Artinya: "Barang siapa yang menyembunyikan ilmu yang bermanfaat, niscaya datang dia pada hari qiamat, pada mulutnya ada kekang dari api neraka" (Diriwayatkan Ibnu Majah dari Abi Sa'id dengan isnad dla'if).

Selain itu, Allah Ta'ala berfirman:

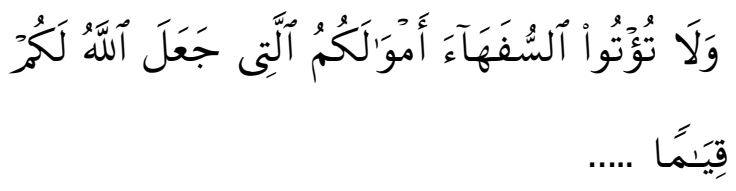

Artinya: "Dan janganlah kamu serahkan kepada orang-orang yang belum sempurna akalnya, harta (mereka yang ada dalam kekuasaanmu) yang dijadikan Allah sebagai pokok kehidupan..." (An-Nisa': 5).

Firman tersebut sebagai peringatan bahwa menjaga ilmu pengetahuan dari orang yang merusakkan dan mendatangkan kemelaratan, adalah lebih utama lagi. Dan tidaklah kurang dzalimnya antara memberikan kepada yang tidak berhak dan tidak memberikan kepada yang berhak.

Tugas ketujuh: kepada seorang pelajar yang singkat paham, hendaklah diberikan pelajaran yang jelas, yang layak baginya. Janganlah disebutkan padanya, bahwa dibalik yang diterangkan ini, ada lagi pembahasan yang mendalam yang disimpan, tidak 
dijelaskan. Karena, yang demikian itu, mengakibatkan kurang keinginannya pada pelajaran yang jelas itu dan mengacau-balaukan pikirannya. Sebab menimbulkan dugaan kepada pelajar itu nanti, seolah-olah gurunya kikir, tak mau memberikan ilmu itu kepadanya.

Sekalian orang menyangka bahwa dirinya ahli dalam segala ilmu, meskipun yang pelik. Dan tak ada seorangpun yang tak ingin memperoleh pikiran yang cerdas dari pada Allah Ta'ala. Orang yang paling dungu dan paling bodoh pun merasa gembira dengan kesempurnaan akal pikirannya.

Dan dengan ini, dapatlah diketahui, bahwa orang awwam yang terikat dengan ikatan kepercayaan agama dan meresap dalam jiwanya 'aqidah yang bersal dari ulama-ulama terdahulu, tanpa membandingkan dan mena'wilkan dan dalam pada itu, bathinnya cukup baik dan akalnya tidak berpikir lebih banyak dari itu, maka tidak sewajarnyalah 'aqidah orang awwam itu dikacau balaukan. Tetapi sewajarnyalah dia itu dibiarkan dengan urusannya. Sebab kalau diterangkan kepada si awwam itu pena'wilanpena'wilan dari kedza-liman kata-kata maka terlepaslah apa yang terikat dalam hatinya. Dan tidak mudah lagi mengikatnya kembali dengan apa yang diikatkan oleh orang tertentu (orang alkhawwash). Lalu terangkatlah dinding antara antara si awwam tadi dan perbuatan ma'siat. Dan bertukarlah dia menjadi setan penggoda, membinasakan dirinya sendiri dan orang lain.

Bahkan, tidak layak orang awwam itu dibawa berkecimpung kedalam ilmu hakikat yang pelik-pelik. Tetapi, cukupkan saja dengan mengajari peribadatan, mengajari amanah dalam pekerjaannya sehari-hari. Isikanlah jiwanya dengan keinginan kepada sorga dan ketakutan kepada neraka seperti yang tersebut dalam Al-Quran Suci.

Jangan dibangunkan pikiran mereka kearah keragu-raguan. Karena mungkin nanti keragu-raguan itu melekat dalam hatinya dan sukar dilepaskannya. Maka binasalah dan celakalah dia kesudahannya. Pendek kata, tidak wajar pintu pembahasan di buka kepada orang awwam. Sebab dengan itu membawa kepada kekosongan pekerjaan mereka, yang menjadi sendi dari budi pekerti dan kekekalan hidup dari orang-orang tertentu.

Tugas kedelapan: guru itu harus mengamalkan sepanjang ilmunya. Jangan perkataannya membohongi perbuatannya. Karena ilmu dilihat dengan mata hati dan amal dilihat dengan mata kepala. Yang mempunyai mata kepala adalah lebih banyak.

Berfirman Allah Ta'ala:

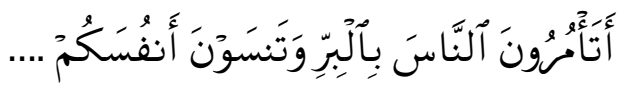

Artinya: "Mengapa kamu suruh orang lain (mengerjakan) kebaktian, sedang kamu melupakan diri (kewajiban) mu sendiri...." (Q.S. Al-Baqarah: 44).

Karena itulah, dosa orang yang berilmu mengerjakan perbuatan ma'siat, adalah lebih besar dari dosa orang yang bodoh. Karena dengan terperosoknya orang yang berilmu, maka terperosoklah orang banyak yang menjadi pengikutnya. Barang siapa membuat tradisi yang buruk, maka berdosalah dia dan berdosalah orang yang menuruti tradisi itu.

Dari itu berkata Ali ra: "Ada dua orang yang mendatangkan bala bencana kepada kita, yaitu orang yang berilmu yang tak menjaga kehormatan dan orang yang bodoh yang kuat beribadah. Orang yang bodoh itu menipu manusia dengan peribadatannya dan orang berilmu itu menipu manusia dengan 
kelengahannya" (Imam al-Ghazali, 2003: 212-223).

\section{Pandangan Guru Profesional menurut Buya Hamka}

Menurut Buya Hamka guru yang profesional adalah guru yang berhasil di dalam pekerjaannya dan mendidik muridnya mencapai kemajuan, ialah guru yang tidak mencukupkan ilmunya dari sekolah guru saja, tetapi di perluasnya pengalaman, dan bacaan. Senantiasa teguh hubungannya dengan kemajuan modern dan luas pergaulannya, baik dengan wali murid atau dengan sesama guru, sehingga menambah ilmu tentang soal pendidikan. Rapat hubungannya dengan orang-orang tua dan golongan muda supaya dia sanggup mempertalikan zaman lama dengan zaman baru, dan dapat disisihkannya mana yang antah dan mana yang beras.

Seorang guru profesional hendaklah menjadi penunjuk bagi muridnya, pembuka kunci akalnya dan memperluas lapangan usahanya. Selain itu seorang guru haruslah bisa menjadi contoh yang baik bagi muridnya, perangai dapat ditiru, menjadi ayah bagi murid-muridnya, menjadi sahabat tempat menumpahkan perasaan hati dan mengadu di waktu pikiran tertumpuk. Bergaul dengan muridmurid itu dengan sikap lemah lembut, tetapi tidak tersudut, keras tetapi penyayang, lemah lembut, tetap merdeka dan bebas, terus terang dan tidak sembunyi-sembunyi, kadangkadang sikapnya keras, tetapi di dalam kerasnya itu si murid merasa sendiri, bahwa pada waktu itu, memang sudah seadilnya jika gurunya keras padanya, kekerasan sekali-kali, samalah artinya garam penambah enaknya sambal (Hamka, 2001: 70-71).
Dari pemikiran Buya Hamka di atas dapat disimpulkan bahwa guru profesional menurut Buya Hamka yaitu: (1) Seorang guru profesional adalah seorang guru yang mempunyai cukup ilmu, tidak mencukupkan ilmunya dari sekolah formal saja. Selain itu, seorang guru profesional senantiasa menambah ilmunya dengan mencari pengalaman dan bacaan buku-buku yang dibutuhkan untuk memperkuat ilmunya: (2) Seorang guru profesional mengikuti perkembangan dan kemajuan, sehingga tidak tertinggal dengan masalah-masalah yang aktual, terutama dalam bidang yang ditekuni; (3) Seorang guru profesional memiliki pergaulan yang luas, baik dengan wali murid atau dengan sesama guru, sehingga menambah ilmu tentang soal pendidikan, dan erat hubungannya dengan orang-orang tua dan golongan muda supaya dia sanggup mempertalikan zaman lama dengan zaman baru, dan dapat disisihkannya mana yang antah dan mana yang beras; (4) Seorang guru profesional dapat memberikan petunjuk kepada para peserta didiknya, sebab bagaimanapun seorang guru adalah seorang yang telah dianggap telah dewasa dan telah banyak mempunyai pengalaman, terutama dalam hal pengetahuan; (5) Seorang guru profesional seharusnya dapat membantu membuka pikiran para peserta didiknya; (6) Seorang guru profesional senantiasa memperluas lapangan usaha peserta didiknya dengan memberikan alternatifalternatif yang mungkin dapat ditempuhnya. Seorang guru seyogianya mampu mendorong para peserta didik untuk menciptakan peluang-peluang, kesempatan-kesempatan, terutama dalam masalah kerja; (7) Seorang guru profesional tidak hanya dapat mentransfer ilmu kepada para peserta didiknya, tetapi juga dapat 
menanamkan nilai-nilai yang baik dengan cara mendidik mereka dengan budi, persaudaraan dan persatuan, kerukunan dan kepercayaan kepada diri sendiri; (8) Seorang guru profesional seharusnya dapat menjadi contoh yang baik dalam hal budi pekerti (9) Seorang guru seharusnya dapat melindungi sebagai seorang ayah, dapat menjadi tempat mengadu bagi para peserta didiknya; dan (10) Seorang guru dalam mengajar tujuan utamanya adalah mengharapkan keridlaan Allah Swt, bukanlah sekedar mencari makan dan mencari gaji (Hamka, 2001: 241).

\section{SIMPULAN}

Guru profesional menurut Imam al-Ghazali adalah seorang guru yang mengikuti jejak Rasulullah dalam tugas dan kewajibannya, menegur kesalahan melalui sindiran, mempunyai kesabaran dalam mengajar dan tidak menambah pelajaran sebelum siswa faham, Memiliki prinsip, arif dan kasih sayang terhadap anak didik, menjadi teladan bagi anak didik, memberikan pelajaran sesuai tingkat pemahaman si murid, memberikan pelajaran yang jelas dan terang, menghormati kode etik guru dan harus cerdas dan sempurna akalnya.

Sedangkan guru profesional menurut Buya Hamka yaitu seorang guru yang mempunyai cukup ilmu, mampu mengikuti perkembangan dan kemajuan zaman, luas pergaulannya dengan masyarakat, dapat memberikan petunjuk kepada para peserta didiknya, dapat membantu membuka pikiran para peserta didiknya, memperluas lapangan usaha peserta didiknya, tidak hanya dapat mentransfer ilmu kepada para peserta didiknya tetapi juga dapat menanamkan nilai-nilai akhlak mulia, dapat menjadi contoh yang baik dalam hal budi pekerti, dapat melindungi seperti seorang ayah, dapat menjadi tempat mengadu bagi para peserta didiknya dan tujuan utama mengajar baginya adalah untuk mengharapkan keridlaan Allah Swt.

Persamaan pendapat Imam alGhazali dan Buya Hamka, yaitu: Imam al-Ghazali dan Buya Hamka sependapat bahwa guru profesional harus menjadi teladan bagi anak didik, memiliki prinsip, arif dan kasih sayang terhadap anak didik, mengajar bukanlah tujuan utamanya gaji, tapi ikhlas dan mengharap ridla Allah Swt. Dan harus cerdas akalnya.

Perbedaan pendapat Imam alGhazali dan Buya Hamka, yaitu pada pendapat Imam al-Ghazali: Seorang guru harus menegur dengan cara sindiran, mempunyai kesabaran dalam mengajar dan tidak menambah pelajaran sebelum siswa faham, Menyingkatkan pelajaran menurut tenaga pemahaman si murid, memberikan pelajaran yang jelas dan terang, menghormati kode etik guru. Sedangkankan menurut Buya Hamka: Seorang guru (profesional) seharusnya mampu mengikuti perkembangan zaman, dapat memberikan petunjuk kepada para peserta didiknya, dapat membuka pikiran para peserta didiknya, mampu menciptakan siswa yang mempunyai skill, dan selain ilmu seorang guru (profesional) juga harus mampu mendidik akhlak siswa.

Imam al Ghazali dan Buya Hamka memandang bahwa guru mesti ahli (menguasai ilmunya), cerdas, memiliki prinsip kritis, menjadi tauladan bagi peserta didik dan kode etik, dan lain-lain. Semua hal tersebut sangat perlu dimiliki oleh seorang guru termasuk pada zaman sekarang, itu artinya dapat dikatakan Imam alGhazali dan Buya Hamka telah meletakkan dasar yang penting bagi seorang guru yang profesional, itu 
artinya pemikiran Imam al-Ghazali dan Buya Hamka masih relevan.

\section{DAFTAR RUJUKAN}

Ahmad, M. Yusuf. 2011. Kompetensi Guru Perspektif Al-Ghazali. Pekanbaru: Pusat Kajian Pendidikan Islam FAI UIR.

Al-Ghazali, Imam. 2007. Ringkasan Ihya Ulumuddin, Penerjemah Zeid Husein Al-Hamid. Jakarta: Pustaka Amani.

Anwar, Desy. 2003. Kamus Lengkap Bahasa Indonesia Terbaru Dilengkapi Pedoman Umum Ejaan Bahasa Indonesia Yang Disempurnakan. Surabaya: Amelia. Arifin, Anwar. 2007. Profil Guru dan Dosen Indonesia Idealis, Profesional, Sejahtera. Jakarta: Pustaka Indonesia.

Bastian, Adolf. Mutu Guru Masih Rendah. Tabloid Bahtera Ilmu, Edisi Ke 2.

Tahun I, Maret 2012.

Daradjat, Zakiah. 1982. Kepribadian Guru. Jakarta:Bulan Bintang.

Dunya, Sulaiman. 2002. Al Haqiqat Pandangan Hidup Imam Al Ghazali. Surabaya: Pustaka Hikmah Perdana.

Guza, Afnil. 2009. Undang-Undang Guru dan Dosen. Jakarta: Asa Mandiri.

Haris, Abd., 2010. Etika Hamka Kontruksi Etik Berbasis Rasional Religius. Yokyakarta: LKIS.

Hamka. 1980. Lembaga Budi. Jakarta: Yayasan Nurul Islam.

Hamka. 1966. Lembaga Hikamat, Bulan Bintang.

Hamka. Lembaga Hidup, Pustaka Panji Mas, Jakarta, 2001.

Kunandar. 2011. Guru Profesional Implementasi Kurikulum Tingkat Satuan Pendidikan (KTSP) dan Sukses Dalam Sertifikasi Guru, Jakarta: PT. Raja Grafindo
Persada. Muhammad, Imam Abi Hamid. 1939. Ihya Ulumuddin. Maktabah Wa Muthabaqah.

Moleong, Lexy J., 2000. Metodologi Penelitian Kualitatif . Bandung: PT Rosdakarya.

Muhajir, Noeng. 1998. Metode Penelitian Kuantitatif. Yogyakarta: Rake Sarasin.

Muhammad Anas. 2009. Nilai-Nilai Pendidikan Akhlak Dalam Kitab Berjanzi. Skiripsi pada program Strata 1 (S1) Fakultas Ilmu Agama Islam Universitas Islam Indonesia Yogyakarta.

Muhammad Ali Syofyan. Konsep Pendidikan Akhlak Dalam Perspektif Pemikiran Buya Hamka. Skiripsi pada program Strata 1 (S1) Fakultas Agama Islam Universitas Islam Riau. Pekanbaru. 2011.

Mulyasa, E., 2011. Standar Kompetensi dan Sertifikasi Guru. Bandung: PT. Remaja Rosdakarya.

Pedoman Umum Ejaan Bahasa Indonesia Yang Disempurkan EYD. Berdasarkan Keputusan Menteri Pendidikan dan Kebudayaan Republik Indonesia Nomor 0543a/U/1997. Tanggal 9 September 1997.

Ramayulis dan Nizar, Samsul. 2005. Ensiklopedi Tokoh Pendidikan Islam Mengenal Tokoh Pendidikan Islam Di dunia Islam Dan Indonesia, Quantum Teaching.

Sagala, Syaiful. 2011. Kemampuan Profesional Guru dan Tenaga Kependidikan. Bandung: Alfabeta.

Sembiring, M. Gorky. 2009. Mengungkap Rahasia dan Tips Manjur Menjadi Guru Sejati. Yogyakarta: Best Publisher.

Sosilo Riwayani \& Suci Nuranisyah. Kamus Lengkap 950.000.000 Inggris-Indonesia indonesia Inggris Dilengkapi Tenses \& Irregular-Verb 
Serta Pengetahuan Umum Untuk SD, SLTP, SMU \& UMUM, Sinar Terang Surabaya.

Sukmadinata, Nana Syaodih. 1979. Pengembangan Kurikulum Teori dan Praktek. Bandung: Remaja Rosdakarya.

Sjadzali, Munawir. 1993. Islam dan Tata Negara: Ajaran, Sejarah dan Pemikiran. Jakarta: Universitas Indonesia Press.

Slameto. 2003. Belajar dan FaktorFaktor yang mempengaruhinya. Jakarta: Penerbit Rineka Cipta.
Thobanah, Badawi. t.t. Al-Ghazali, Iḥyā' 'Ulūmuddīn juz 3. Semarang: Toha Putra.

Tolkhah, Imam dan Barizi, Ahmad. 2004. Membuka Jendela Pendidikan. Jakarta: PT. Grafindo Persada.

Usman , Moh. Uzer. 2005. Menjadi Guru Profesional. Bandung: PT. Remaja Rosda Karya.

Yunus, Mahmud. 2009. Kamus ArabIndonesia. Jakarta: PT. Hidakarya Agung.

Zainuddin. 1991. Seluk Beluk Pendidikan dari Al Ghazali. Jakarta: Bumi Aksara. 